Plant Tissue Cult. \& Biotech. 22(1): 83-86, 2012 (June)

\title{
Estimation of Genome Size of Jute (Corchorus capsularis (L.) var. CVL-1 using Flow Cytometry
}

\section{Ryo Akashi ${ }^{1}$, Nurun N. Fancy, Arif M. Tanmoy and Haseena Khan*}

Department of Biochemistry and Molecular Biology, University of Dhaka, Dhaka-1000, Bangladesh

Key words: Corchorus capsularis, Flow cytometry, Genome size

Genome size is an informative biological marker in understanding its complexity. Moreover, selection of breeding material(s) largely depends on the size of the parental genome. In this study, genome size of one of the most important natural fibers, jute (Corchorus capsularis) is reported. Flow cytometry was used, since it can provide an accurate estimation. The estimated size of the haploid genome (1C) of jute (Corchorus capsularis var. CVL-1) was found to be $274 \pm 10.7 \mathrm{MbpC}^{-1}$. This information should be helpful to shed more light on the evolutionary history of the genus Corchorus regarding their phylogenetic relationships and chromosomal evolutions as well as selection of breeding material(s) for hybridization.

Genome size of an organism can be used as a useful taxonomic marker which is one of the salient features defining a species (Ohri 1998, Bennett et al. 2008). It could provide useful information for the analysis of phylogenetic relationships and contribute to the understanding of the complexity of genomes (Doležel 1997). Therefore, it is essential not only for the overall understanding of the genome of a single species, but for overall biological interest. Moreover, the information can serve as a critical factor in the selection of parental material(s) for hybridization (Doležel 1997, Jung et al. 2004, Ochatt 2008, Zaitlin and Pierce 2010).

The genus Corchorus consists of over 170 (Mahapatra and Saha 2008) annual or short-lived perennials (Benor et al. 2010) distributed in tropical, sub-tropical and warm temperate regions of the world. It represents two of the cultivated jute species, C. capsularis L. (the white jute) and C. olitorius L. (the tossa jute/ Jew's mellow). Both are economically important in Bangladesh and India. However, as compared to other economically important crop species, genetic research on Corchorus is not very advanced to date (Karmakar et al. 2008).

\footnotetext{
*Author for correspondence: <haseena@du.ac.bd $>$ 'Frontier Science Research Center, 1-1 Gakuen Kibana-dai Nishi, Miyazaki-shi, University of Miyazaki, Miyazaki 889-2192, Japan. $<$ rakashi@cc.miyazaki-u.ac.jp>.
} 
Seeds of C. capsularis var. CVL-1 were germinated aseptically on MS medium containing $3 \%$ sucrose and $0.3 \%$ gelrite and 4 days old seedlings were collected.

Flow cytometry method (FCM) was used to estimate genome size of the Corchorus variety according to Galbraith et al. (1983) with a few modifications. Approximately $1.0 \mathrm{~cm}^{2}$ of young leaf of Brachiaria ruziziensis (ruzi) and $1.0 \mathrm{~cm}^{2}$ of young leaf of Corchorus capsularis var. CVL-1 were excised and placed in $90 \mathrm{~mm}$ Petri dishes. The excisates were soaked with $1 \mathrm{ml}$ of extraction buffer containing $50 \mathrm{mM}$ Tris-HCL, $0.5 \%$ polyvinylpyrrolidone, $0.01 \%$ triton- $X$ and $0.63 \%$ sodium sulfite for $5 \mathrm{~min}$ and chopped finely with a razor blade. The suspension including nuclei was filtered through a 50- $\mu \mathrm{m}$ nylon mesh and centrifuged at $3300 \mathrm{~g}$ for $2 \mathrm{~min}$. After removal of the supernatant, extraction buffer supplemented with $50 \mu \mathrm{g} / \mathrm{ml}$ RNase was added and the suspension was incubated for $30 \mathrm{~min}$ at room temperature. To stain nuclei completely, $50 \mu \mathrm{l}$ propidium iodide (PI) was added and the suspension was kept at room temperature for at least $5 \mathrm{~min}$. Fluorescence intensities of the samples were measured by EPICS XL, equipped with a $488 \mathrm{~nm}$ argon laser and long path filter (Beckman Coulter, Inc., Tokyo, Japan). Genome size of Corchorus capsularis var. CVL-1 cultivar was estimated by comparing the fluorescence intensity of the samples with that of Brachiaria ruziziensis (ruzi) as a reference which is known to possess $615 \mathrm{MbpC}^{-1}$ (Ishigaki et al. 2010). This analysis was replicated three times for the variety.

The $C$ value was used in the estimation of the genome size. This value describes the DNA content per holoploid (with chromosome number, $n$ ), which represents the complete chromosome complement; irrespective of the ploidy level (Greilhuber et al. 2005). The amount of nuclear DNA of the Corchorus capsularis var. CVL-1 sample is calculated according to the method of Doležel (1997) by the simple formula as follows.

Sample $1 \mathrm{C}$ value $(\mathrm{DNA}$ pg or $\mathrm{Mbp})=$ Reference $1 \mathrm{C}$ value $\times($ sample $2 \mathrm{C}$ mean peak position/ reference $1 \mathrm{C}$ mean peak position).

In this study, the haploid genome size of Corchorus capsularis var. CVL-1 was found to be $274 \pm 10.7 \mathrm{Mbp}$ (mean \pm standard deviation) (Fig. 1) which is the second smallest genome size among all $C$. capsularis varieties estimated by Sarkar et al. (2011). They have shown the $1 C$ value of the white jute (C. capsularis) to be approximately $280 \mathrm{Mb}$, which is $\sim 300 \%$ smaller than the previous reported estimate by Samad et al. (992). Thus authors' result is almost consistent with the findings of Sarkar et al. (2011) and in accordance with typical karyomorphological studies performed on wild species of jute (Maity and Datta 2009). 


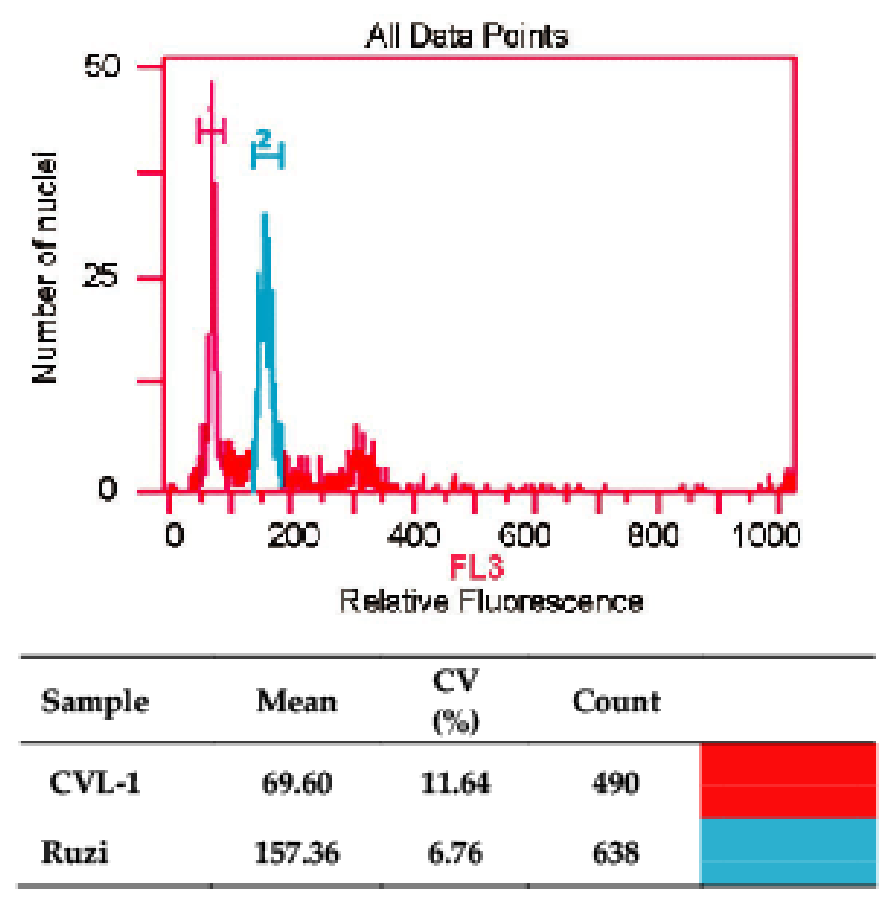

Fig. 1. Estimation of nuclear DNA content in absolute units. C. capsularis var. CVL-1 DNA content measured from FCM procedures taking the Brachiaria ruziziensis (ruzi) as the reference sample. Histograms showing peaks with CVs ranging between 11.64 and $16.49 \%$ (value not shown) for CVL-1, obtained from PI-stained nuclear suspensions. The $1 \mathrm{C}$ mean peak position of the sample CVL-1 was found 69.60 , resulting a haploid genome size of $274 \pm 10.7 \mathrm{MbpC}^{-1}$.

The estimation of genome size is important for its contribution in facilitating future genome research (Gregory et al. 2007). It would be useful for shedding more light on the evolutionary history of genus Corchorus to decipher the phylogenetic relationships and chromosomal evolution of the extant species. In addition, the cumulative information regarding the genome size of different organisms will facilitate to resolve the mystery of the molecular and evolutionary mechanisms behind the disparity of genome size(s) both within and among species.

\section{Acknowledgements}

Authors are grateful to Bangladesh Jute Research Institute for providing jute seeds used in this study.

\section{References}

Bennett MD, Price HJ and Johnston JS (2008) Anthocyanin inhibits propidium iodide DNA fluorescence in Euphorbia pulcherrima: implications for genome size variation and flow cytometry. Annals of Botany 101(6): 777-790. 
Benor S, Blattner FR, Demissew S and Hammer K (2010) Collection and ethnobotanical investigation of Corchorus species in Ethiopia: potential leafy vegetables for dry regions. Genetic Resources and Crop Evolution 57(2): 293-306.

Doležel J (1997) Application of flow cytometry for the study of plant genomes. Journal of Applied Genetics (Poland); formerly Genetica Polonica 38.

Galbraith DW, Harkins KR, Maddox JM, Ayres NM, Sharma DP and Firoozabady E (1983) Rapid flow cytometric analysis of the cell cycle in intact plant tissues. Science 220 (4601): 1049-1051.

Gregory TR, Nicol JA, Tamm H, Kullman B, Kullman K, Leitch IJ, Murray BG, Kapraun DF, Greilhuber J and Bennett MD (2007) Eukaryotic genome size databases. Nucleic Acids Research 35 (suppl 1): D332-D338.

Greilhuber J, Doležel J, Lysak MA and Bennett MD (2005) The origin, evolution and proposed stabilization of the terms 'genome size' and 'C-value' to describe nuclear DNA contents. Annals of botany 95(1): 255-260.

Ishigaki G, Gondo T, Ebina M, Suenaga K and Akashi R (2010) Estimation of genome size in Brachiaria species. Grassland Science 56(4): 240-242.

Jung G, Curley J, Williamson R and Eaton T (2004) Determination of the level of variation in polyploidy among Kentucky bluegrass cultivars by means of flow cytometry. Crop science 44(6): 2168-2174.

Karmakar PG, Hahn MG, Ramasubramanian T, Mandal RK, Sinha MK and Sen HSE (2008) Cytogenetics, mutagenesis and genetics of qualitative characters of jute and allied fibre crops. Jute and Allied Fibre Updates, Kolkata, Central Research Institute for Jute and Allied Fibres: 46-56.

Mahapatra AK and Saha A (2008) Genetic resources: jute and allied fibre corps. Jute and allied fibre updates, Kolkata, Central Research Institute for Jute and Allied Fibres: 18-37.

Maity S and Datta AK (2009) Karyomorphology in Nine Species of Jute (Corchorus L., Tiliaceae). Cytologia 74(3): 273-279.

Ochatt SJ (2008) Flow cytometry in plant breeding. Cytometry part A 73 (7): 581-598.

Ohri D (1998) Genome size variation and plant systematics. Annals of Botany 82 (suppl 1): 75-83.

Samad M, Kabir G and Islam A (1992) Interphase nuclear structure and heterochromatin in two species of Corchorus and their F1 hybrid. Cytologia 57(1): 21-25.

Sarkar D, Kundu A, Saha A, Mondal NA, Sinha MK and Mahapatra BS (2011) First nuclear DNA amounts in diploid $(2 \mathrm{n}=2 \mathrm{x}=14)$ Corchorus spp. by flow cytometry: Genome sizes in the cultivated jute species (C. capsularis L. and C. olitorius L.) are $\sim 300 \%$ smaller than the reported estimate of 1100-1350 Mb. Caryologia 64(2): 147.

Zaitlin D and Pierce AJ (2010) Nuclear DNA content in Sinningia (Gesneriaceae); intraspecific genome size variation and genome characterization in S. speciosa. Genome 53(12): 1066-1082. 